\title{
Knowledge, Practice and Involvement of University Community in Environmental Activities Connected to Polystyrene
}

\author{
Zanaton H. Iksan, Ahmad Sarji Abdul Hamed \\ Faculty of Education, Universiti Kebangsaan Malaysia, Bandar Baru Bangi, Malaysia \\ Email: zanaton.iksan@ukm.edu.my
}

How to cite this paper: Iksan, Z. H., \& Hamed, A. S. A. (2019). Knowledge, Practice and Involvement of University Community in Environmental Activities Connected to Polystyrene. Creative Education, 10, 1777-1791.

https://doi.org/10.4236/ce.2019.108127

Received: May 30, 2019

Accepted: August 3, 2019

Published: August 6, 2019

Copyright $\odot 2019$ by author(s) and Scientific Research Publishing Inc. This work is licensed under the Creative Commons Attribution International License (CC BY 4.0).

http://creativecommons.org/licenses/by/4.0/

(c) (i) Open Access

\begin{abstract}
This study can contribute to enhancing knowledge of the impact on polystyrene use and environmental care in the National University of Malaysia efforts to become a sustainable campus by 2020 . This study aims to look at the level of knowledge, practices and engagement of UKM residents in the context of polystyrene use within the university campus. There were 381 samples consisting of undergraduate students, postgraduate students and staffs of UKM. A questionnaire with Cronbach's alpha 0.89 was used as data collecting tools; all data were analysed using the Statistical Package for Social Sciences (SPSS version 16). The study found that the level of knowledge about polystyrene among UKM people is at a good level. Practices about the use of polystyrene and its implications for the environment among UKM citizens and involvement in environmental activities were at a moderate level. The knowledge about polystyrene does not lead to good practice and involvement in environmental activities related to polystyrene. This is because UKM management only sets a ban on the polystyrene in café and food premises in the campus and allows residents to carry polystyrene from outside premises from UKM. UKM needs to expand the enforcement of polystyrene use restrictions within the campus to make sure that the campus area is free of polystyrene.
\end{abstract}

\section{Keywords}

Environmental Activities, Involvement, Knowledge, Practice, Sustainable Campus

\section{Introduction}

The National University of Malaysia (Universiti Kebangsaan Malaysia, UKM) has introduced a method of using environmentally friendly food containers to 
replace the use of polystyrene in the campus. This is because students and sellers are found to still use polystyrene as an important food packaging material in the process of buying and selling. According to Saidi and Er (2016), the use of environment-friendly food packaging is less applied and less practiced by UKM residents as there are less awareness and exposure to eco-friendly food products. The use of polystyrene should be fully resolved in order to ensure that the environmental care practices by all UKM citizens are at the best. Therefore, if the use of polystyrene by UKM students can be directly overcome, then the awareness of the importance among students is increased. Many scholars argued that the best way to overcome environmental problems is to change the attitude and everyday practice of society from self-interest to focusing on the environment (Callicott, 2000).

Additionally, polystyrene trash from all over UKM is a lot and causes a lot of garbage in the UKM campus. Prof Datin Dr Noor Aziah Mohd Awal, Deputy Vice Chancellor of Student Affairs and Alumni UKM said in her speech at the Opening Ceremony of Zero Polystyrene in UKM on 1 April 2015, the university is generating a lot of garbage, consisting of too much polystyrene and plastic bags that they get out of the bins provided and caused pollution in the university (Kamaruddin, 2015). There are many adverse effects resulting from the dumping of polystyrene trash in the UKM campus which includes environmental imbalance and ecosystem damage as well as causing harmful diseases to humans and animals. This is because polystyrene has chemical compositions that are harmful to life and the universe. The solid waste of polystyrene should be urgently reduced in order to generate good environmentally friendly practices among the student thus saving the environment from being contaminated.

The lack of participation of students in the environmental program carried out by the university is an issue that becomes a constraint to the effectiveness of environmental programs within the campus. This is demonstrated by the study conducted by Derahim, Ali and Saadiah (2011) that the majority of students at Universiti Kebangsaan Malaysia are less prepared to manage sustainable development activities and programs for university community and the community outside the campus. The lack of involvement by the community of Universiti Kebangsaan Malaysia in knowledge and outdoors programs on environmental sustainability has been causing the lack of deep knowledge and awareness in the development of nature conservation. The findings of Veratharaju and Idros (2008) found that an increase of knowledge among students over a long period would result in a more sensitive and attentive citizen and society on environmental issues and recycling as well as promoting awareness, skills, value, commitment and meaningful experience to strive and act individually or holistically towards solving the environmental issues. Having knowledge will increase the awareness and concern (attitude) and thus create an individual who has more positive attitude towards the environment (Kollmuss \& Agyeman, 2002).

Commitment to the environment is a new theoretical construct that predicts environmentally friendly behaviour (Davis, O’Callaghan, \& Knox, 2009). Cur- 
rent students do not implement environmental care practices. The practice of polystyrene use by university community led to the scattering of the wrapping material everywhere. The dumping of this polystyrene rubbish indicates the unhealthy practices by university students are still continuing. Students seem less responsible towards the environment. Ahmad, Mustafa, Hamid and Wahab (2011) stated that the rapid development and the less-responsible attitude of the society have led to a negative impact on the environment and the quality of life.

\section{Research Questions}

Based on the problem statement that has been discussed, there are several questions that need to be answered that are:

1) What is the level of knowledge about the advantages and disadvantages of polystyrene against environmental sustainability among UKM community?

2) What is the level of practice in the context of polystyrene use and its implications for the environment among UKM community?

3) What is the rate of involvement in environmental programs and activities organized by the university administration among UKM community?

4) Is there any relationship between knowledge and practice of polystyrene use and the relationship between knowledge and involvement of UKM community in environmental activities?

\section{Literature Review}

Environmental issues are not a new issue in the country. This issue is often becoming a hot debate among many parties. A lot of studies have been conducted on environmental issues in order to find the causes and solutions. However, environmental issues still could not be solved thoroughly. As discussed in the study by Ahmad et al. (2011), the level of knowledge of the respondents towards the environment is at an unsatisfying level. The study also stated that respondents needed more exposure or explanation in improving their knowledge as well as fixing their attitudes and practices towards the environment. This suggests that people's awareness is still low on the importance of preserving the environment for a harmonious future. In addition, environmental awareness should also be exposed early to the younger generation so that they will become more aware of it thus producing a community that is able to better preserve the nature. An increase in students' knowledge over a long period of time will produce citizens and communities who are more sensitive and attentive towards the environmental and recycling issues as well as inculcate skills, values, commitments and meaningful experiences to work and act individually or holistically towards solving environmental issues (Veratharaju \& Idros, 2008).

University is one of the best educational institutions in Malaysia in producing holistic society in terms of intellectual, spiritual, emotional and physical. In the environmental issue, many programs have been carried out by the university in ensuring that its community can be citizens who love nature. The establishment 
of sustainable campuses is important to ensure a comfortable and healthy environment for the community. Derahim et al. (2011) in her study stated that UKM should devise and implement capacity-building programs on sustainability among its communities especially students, in order to achieve the university's desire to produce a sustainable campus by 2020. Direct and comprehensive community involvement is important in improving the sustainability of the campus.

Polystyrene is an economic food packaging material but it has a lot of adverse effects on consumers and the environment. Polystyrene is widely used everywhere and polystyrene rubbish is not disposed properly, thus bringing bad effects to the world (dana Gopal, Phebe, Kumar, \& Vani, 2014). The use of polystyrene in the UKM campus is an issue that needs to be solved immediately. UKM should ensure its campus is free from polystyrene problems in an effort to become an environmentally friendly educational institution as well as to create a community which are aware of environment.

However, studies conducted in UKM by Saidi and Er (2016) found that students are aware of the disadvantages of using non-environmentally friendly products such as polystyrene. However, even though they know that polystyrene packs lead to long-term hazards; students do not have the initiative to change to eco-friendly packing because they do not know the channels to get the eco-friendly packaging. In addition, polystyrene food packaging and plastic is widely used in the campus especially in residential college cafes. The findings provide clear questions about the level of students' knowledge about polystyrene and practices that lead to the use of polystyrene.

\section{Methodology}

The research method used in this study is a survey which is one of the most popular experimental research methods used in various fields, especially in the field of social science. This study was conducted to obtain information from the respondents on the polystyrene issues related to the knowledge, practice and involvement of UKM community towards polystyrene. Survey method was chosen because according to Chua (2006), survey is a comprehensive study of issues or problems, rapid data collection, use a large sample size, information is directly collected from respondents in a short period of time and can make general statements for a research population.

Konting (2000) stated that the selected sample to participate in the study should have the same characteristics as the population in the research. The sampling method used in this study was simple random sampling method. The population of this study is the community of National University of Malaysia and was classified into three sections namely undergraduate students, postgraduate students, and university staffs. According to statistical reports issued by the Registry of UKM, the total number of UKM employees as of August 2017 is 5485. The population of undergraduate and post-graduate students as reported by the 
Department of Academic Management Department of Universiti Kebangsaan Malaysia as of September 2017 is 14,322 and 8754 students respectively. Based on the total number of the three sections, the total population is 28,561 people. The sample selection was based on sample size tables by Cohen, Manion and Morrison (2001). According to the table, the suitable sample size for this study is 377 people.

This study uses quantitative method that is through survey research design using questionnaire instrument. The questionnaire is divided into three sections: Part A: The respondents' background which includes gender, age, occupation, length of service for staff and study period for students as well as institute and faculty names. Part B contains 35 statements relating to the knowledge, practice and involvement of UKM community in environmental activities. The statement is followed by a modified "Likert" scale into five answer choices: 1 (strongly disagree), 2 (disagree), 3 (moderately agree), 4 (agree) and 5 (strongly agree). Part $\mathrm{C}$ covers three open questions about respondents' views of knowledge, practices and involvement in the environmental activity within the scope of polystyrene use in the campus. Part $\mathrm{C}$ is a qualitative question which is provided to support the findings of quantitative questionnaires. To obtain the validity of the questionnaire, the questionnaire was sent to the accredited individual to be verified before being distributed to the respondents involved. The questionnaire was endorsed by three experts in the field of education and environment and the reliability value of Cronbach's alpha was 0.89 . In the questionnaire, the purpose of the study and the importance of the study along with the words of appreciation to the respondents who collaborated in the study conducted are mentioned.

The questionnaire was directly distributed to all selected respondents by the researcher. Data collection from respondents took three weeks. The data collection process involved a lot of respondents and takes a lot of time and money to complete. Therefore, the researcher put time and financial factors as a study limit. Statistical Package for Social Sciences (SPSS version 16) is used in data collection and processing. This method is used to make descriptive analysis that is frequency, percentage, mean and standard deviation in order to get the result of demography. Normality tests show that the data is abnormally distributed; therefore non-parametric statistical analysis of Mann-Whitney and Kruskal-Wallis tests is used to test the mean. Whereas Spearman correlation test is conducted to identify the strength and direction of correlation which is either strong or weak and also positive or negative based on the correlation coefficient (Baba, 1992) (Table 1).

\section{Findings}

\subsection{Demographic}

Table 2 discusses the percentage and frequency of study respondents' background information. The respondents of this study are of 381 National University of Malaysia (UKM) communities consisting of 176 (46.2\%) males and 205 
Table 1. Correlation coefficient.

\begin{tabular}{cc}
\hline Coefficient & Relationship Strength \\
\hline $0.01-0.20$ & Very Small \\
$0.21-0.40$ & Very Small \\
$0.41-0.60$ & Moderate \\
$0.61-0.80$ & Big \\
$0.81-1.00$ & Very Big \\
\hline
\end{tabular}

Source: Baba (1992).

Table 2. Respondents demographic information.

\begin{tabular}{cccc}
\hline & Background & Frequency & Percentage (\%) \\
\hline \multirow{2}{*}{ Gender } & Male & 176 & 46.2 \\
& Female & 205 & 53.8 \\
\multirow{3}{*}{ Age } & $18-25$ years old & 213 & 55.9 \\
& $26-35$ years old & 90 & 23.6 \\
& $36-45$ years old & 66 & 17.3 \\
& $46-55$ years old & 12 & 3.1 \\
Occupation & & 128 & 33.6 \\
& Undergraduate students & 138 & 36.2 \\
& Postgraduate students & 115 & 30.2 \\
& University staffs & 121 & 31.8 \\
Duration of & $1-2$ years & 170 & 44.6 \\
Study/Work & $3-4$ years & 62 & 16.3 \\
& $5-10$ years & 24 & 6.3 \\
& $11-15$ years & 4 & 1.0 \\
\hline
\end{tabular}

(53.8\%) females. The majority of the respondents were aged between 18 years old and 25 years old with a total of 213 people. This suggests that UKM communities are mostly made up of $\mathrm{Y}$ and $\mathrm{Z}$ generation. There are 128 respondents of undergraduate students, while postgraduate students are 138 and the number of university staff who participated in this study which was 115 people. In addition, the findings of the demographic information of the sample showed that 260 of the total number of respondents are studying or working at Universiti Kebangsaan Malaysia for more than 2 years. This shows that the majority of the respondents have strong knowledge about all the activities carried out by the university including the sustainable campus campaign conducted by UKM.

\subsection{Statistical Test}

1) What is the level of knowledge about the advantages and disadvantages of polystyrene towards environmental sustainability among UKM community?

Table 3 shows the total mean of knowledge about the advantages and disadvantages of polystyrene towards environmental sustainability among UKM community. The findings show that the level of knowledge of UKM community is at a good level with the total mean of 4.00 and the standard deviation of 0.50 . 
Table 3. Total mean of knowledge level.

\begin{tabular}{cccc}
\hline & N & Mean & Standard Deviation \\
\hline Knowledge of polystyrene products & 381 & 4.00 & 0.50 \\
\hline
\end{tabular}

The findings of this study prove that today's community has begun to care about the importance of environmental knowledge.

$\mathrm{H}_{\text {null }}$ : There is no difference in mean of knowledge level about polystyrene products between male and female respondents.

Mann-Whitney statistical test was conducted to test the mean difference of knowledge level about polystyrene products between male and female respondents. The mean rank for male respondents is 186.07 while female respondents are 195.24. The study found that there is no significant difference between the level of knowledge between male respondents and female respondents with $p>$ 0.05 and failed to reject the null hypothesis. This finding suggests that the knowledge of polystyrene products in the community is the same regardless of their gender. Table 4 shows the findings of the SPSS test conducted.

$\mathrm{H}_{\text {null }}$ : There is no difference in knowledge level about polystyrene products based on respondent's occupation.

Kruskal-Wallis statistical test was conducted to test the mean difference of knowledge about polystyrene products based on respondents' occupation. The study found that the mean rank for undergraduate students, postgraduate students and university staffs are 215.31, 149.28 and 214.01 respectively. The findings show that there is a difference in the level of knowledge about polystyrene products based on the respondents' occupation with $p<0.001$ and the null hypothesis is rejected. This indicates that the knowledge of undergraduate students and university staff is higher than post-graduate students based on the mean rank. Table 5 shows the SPSS findings of the test performed.

2) What is the level of practice in the context of polystyrene use and its environmental implications among UKM community?

Table 6 shows the total mean of the practice level in the context of polystyrene use and the environmental implications among UKM students. The findings show that UKM's level of practice is moderate with a mean of 2.99 and a standard deviation of 0.47 .

$\mathrm{H}_{\text {null }}$ : There is no difference in the level of practice in the context of polystyrene use and its implications on environment among UKM community based on gender.

Mann-Whitney's statistical test was conducted to test the mean difference of practice levels in the context of polystyrene use and its implications for the environment among UKM community based on gender. The mean rank for male respondents was 202.14 which are higher than the mean rank of female respondents that is 181.43 . The study found that there is no significant difference in the level of practice in the context of polystyrene use and its environmental implications among UKM community based on gender with $p>0.05$. The level of practice 
Table 4. Mann-Whitney's statistical test findings.

(a)

\begin{tabular}{ccccc}
\hline & Gender & N & Mean Rank & Sum of Ranks \\
\hline Knowledge about Polystyrene & Male & 176 & 186.07 & $32,747.50$ \\
Products & Female & 205 & 195.24 & $40,023.50$ \\
\hline
\end{tabular}

(b)

\begin{tabular}{cc}
\hline & Knowledge about Polystyrene Products \\
\hline Mann-Whitney U & $17,171.500$ \\
Wilcoxon W & $32,747.500$ \\
Z & -0.812 \\
Asymp. Sig. (2-tailed) & 0.417 \\
\hline
\end{tabular}

Table 5. Kruskal-Wallis statistical test findings.

(a)

\begin{tabular}{cccc}
\hline & Occupation & N & Mean Rank \\
\hline \multirow{2}{*}{ Knowledge of polystyrene } & Undergraduate students & 128 & 215.31 \\
products & Postgraduate students & 138 & 149.28 \\
& University staffs & 115 & 214.01 \\
\hline
\end{tabular}

(b)

\begin{tabular}{cc}
\hline & Knowledge about Polystyrene Products \\
\hline Chi-Square & 31.165 \\
$\mathrm{df}$ & 2 \\
Asymp. Sig. & 0.000 \\
\hline
\end{tabular}

Table 6. Total mean of practice level.

\begin{tabular}{cccc}
\hline & N & Mean & Standard Deviation \\
\hline $\begin{array}{c}\text { UKM Community's Practices towards } \\
\text { the Use of Polystyrene }\end{array}$ & 381 & 2.99 & 0.47 \\
\hline
\end{tabular}

of all respondents is not different. The null hypothesis failed to be rejected. Table 7 shows the SPSS findings of the tests performed.

$\mathrm{H}_{\text {null }}$ : There is no mean difference in the level of practice in the context of the use of polystyrene and its implications on the environment among UKM community based on the respondents' occupation.

The Kruskal-Wallis statistical test was conducted to test the mean difference in practice level in the context of polystyrene use and its environmental implications among UKM community based on the respondents' occupation. The study found that mean rank for undergraduate students, postgraduate students and university staffs are $222.73,158.24$ and 195.00 respectively. The findings showed that there is a mean difference in the level of practice in the context of polystyrene use and its implication to the environment among UKM community based on the respondent's occupation with $p<0.001$. The null hypothesis is rejected. 
Table 7. Mann-Whitney's statistical test.

(a)

\begin{tabular}{ccccc}
\hline & Gender & N & Mean Rank & Sum of Ranks \\
\hline UKM Community's Practices & Male & 176 & 202.14 & $35,577.00$ \\
towards the Use of Polystyrene & Female & 205 & 181.43 & $37,194.00$ \\
\hline
\end{tabular}

(b)

\begin{tabular}{cc}
\hline & Knowledge about Polystyrene Products \\
\hline Mann-Whitney U & $16,079.000$ \\
Wilcoxon W & $37,194.000$ \\
Z & -1.835 \\
Asymp. Sig. (2-tailed) & 0.067 \\
\hline
\end{tabular}

This indicates that undergraduate students practice environmental care in the context of polystyrene use compared to university staffs and postgraduate students based on mean rank. Table 8 shows the findings of the SPSS test conducted.

3) What is the rate of involvement in environmental programs and activities organized by the university administration among UKM community?

Table 9 shows the total mean of the rate of involvement in the environmental programs and activities organized by the university administration among UKM community. The findings show that the rate of involvement in environmental programs and activities organized by the university administration is a moderate level with a mean of 3.29 and a standard deviation of 0.64 . The findings show that UKM community still do not involved in the environmental activities organized by the administration as a whole.

$\mathrm{H}_{\text {null }}$ : There is no mean difference in the rate of involvement in environmental programs and activities organized by the university administration among UKM community based on gender.

Mann-Whitney's statistical test was conducted to test the difference in the mean of involvement rate in environmental programs and activities organized by the university's administration among UKM community based on gender. The mean rank for male respondents is 190.12 which are higher than the mean rank of female respondents that is 191.76. The study found that there is no difference in the level of involvement in environmental programs and activities organized by the university administration among UKM community based on gender with $p>0.05$. The rate of involvement of all UKM community in the environmental activities is similar which is at a moderate level. The null hypothesis failed to be rejected. Table 10 shows the SPSS findings of tests performed.

$\mathrm{H}_{\text {null: }}$ : There is no mean difference in the level of involvement in the environmental programs and activities organized by the university administration among UKM community based on the respondents' occupation.

Kruskal-Wallis statistical test was conducted to test the difference in mean of 
Table 8. Kruskal-Wallis statistical test findings.

(a)

\begin{tabular}{cccc}
\hline & Occupation & N & Mean Rank \\
\hline \multirow{2}{*}{ UKM Community's Practices } & Undergraduate students & 128 & 222.73 \\
towards the Use of Polystyrene & Postgraduate students & 138 & 158.24 \\
& University staffs & 115 & 195.00 \\
\hline
\end{tabular}

(b)

Knowledge about Polystyrene Products

\begin{tabular}{cc}
\hline Chi-Square & 23.107 \\
$\mathrm{df}$ & 2 \\
Asymp. Sig. & 0.000 \\
\hline
\end{tabular}

Table 9. Total Mean of involvement level.

\begin{tabular}{cccc}
\hline & N & Mean & $\begin{array}{c}\text { Standard } \\
\text { Deviation }\end{array}$ \\
\hline $\begin{array}{c}\text { Involvement of UKM community in environmental } \\
\text { activities organized by UKM }\end{array}$ & 381 & 3.29 & 0.64 \\
\hline
\end{tabular}

Table 10. Mann-Whitney's statistical test.

(a)

\begin{tabular}{ccccc}
\hline & Gender & N & Mean Rank & Sum of Ranks \\
\hline $\begin{array}{c}\text { Involvement of UKM community } \\
\text { in the environmental activities } \\
\text { organized by UKM }\end{array}$ & Male & 176 & 190.12 & $33,461.00$ \\
& Female & 205 & 191.76 & $39,310.00$ \\
\hline
\end{tabular}

(b)

\begin{tabular}{cc}
\hline & $\begin{array}{c}\text { Involvement of UKM community in the environmental } \\
\text { activities organized by UKM }\end{array}$ \\
\hline Mann-Whitney U & $17,885.000$ \\
Wilcoxon W & $33,461.000$ \\
Z & -0.145 \\
Asymp. Sig. (2-tailed) & 0.885 \\
\hline
\end{tabular}

involvement rate in the environmental programs and activities organized by university administration among UKM community based on respondents' occupation. The study found that mean rank for undergraduate students, postgraduate students and university staffs is $227.00,133.74$ and 219.63 respectively. The findings show that there is a difference in the rate of involvement in the environmental programs and activities organized by the university administration among UKM community based on the respondents' occupation with $p<0.001$. The null hypothesis is rejected. This finding shows that very little involvement among postgraduate students in environmental activities organized by UKM compared to university staffs and undergraduate students based on the mean rank. Table 11 shows the findings of the SPSS test conducted. 
Table 11. Kruskal-Wallis statistical test findings.

(a)

\begin{tabular}{cccc}
\hline & Occupation & N & Mean Rank \\
\hline Involvement of UKM community & Undergraduate students & 128 & 227.00 \\
in the environmental activities & Postgraduate students & 138 & 133.74 \\
organized by UKM & University staffs & 115 & 219.63 \\
\hline
\end{tabular}

(b)

\begin{tabular}{cc}
\hline & $\begin{array}{c}\text { Involvement of UKM community in the environmental } \\
\text { activities organized by UKM }\end{array}$ \\
\hline Chi-Square & 59.018 \\
df & 2 \\
Asymp. Sig. & 0.000 \\
\hline
\end{tabular}

4) Is there any relationship between knowledge and practice of polystyrene use among UKM community?

$\mathrm{H}_{\text {null }}$ : There is no significant relationship between knowledge about the advantages and disadvantages of polystyrene to environmental sustainability and the practice of UKM community on the use of polystyrene.

Spearman correlation test was conducted to test the significant relationship between knowledge about the advantages and disadvantages of polystyrene towards environmental sustainability and the practice of UKM communities on the use of polystyrene. The findings showed that there is no significant relationship between knowledge about the advantages and disadvantages of polystyrene to the environmental sustainability and the practice of UKM community on the use of polystyrene with the significant value $p>0.05$, the strength of the relationship is very low (0.045). The null hypothesis failed to be rejected. Knowledge of UKM residents about the advantages and disadvantages of polystyrene use does not lead to good environmental-friendly practices. Table 12 shows Spearman's correlation test findings.

5) Is there a relationship between knowledge and involvement of UKM communities in environmental activities?

$\mathrm{H}_{\text {null }}$ : There is no significant relationship between the knowledge of the advantages and disadvantages of polystyrene against environmental sustainability and the rate of involvement in environmental programs and activities organized by the university administration among UKM community.

Spearman's correlation test was conducted to test the significant relationship between knowledge of the advantages and disadvantages of polystyrene against environmental sustainability and the rate of involvement in environmental programs and activities organized by university administration among UKM communities. The findings show that there is a significant correlation between knowledge about the advantages and disadvantages of polystyrene towards environmental sustainability and the rate of involvement in environmental programs and activities organized by the university administration among UKM communities with the significant value $p<0.001$, the strength of the relationship is 
Table 12. Spearman's correlation findings for knowledge and practice.

\begin{tabular}{|c|c|c|c|c|}
\hline & & & \multicolumn{2}{|c|}{ Knowledge of polystyrene UKM communities' practices } \\
\hline & & & products & on the use of polystyrene \\
\hline \multirow{7}{*}{ Spearman's rho } & \multirow{3}{*}{$\begin{array}{l}\text { Knowledge of polystyrene } \\
\text { products }\end{array}$} & Correlation Coefficient & 1.000 & 0.045 \\
\hline & & Sig. (2-tailed) & 0.000 & 0.378 \\
\hline & & $\mathrm{N}$ & 381 & 381 \\
\hline & \multirow{4}{*}{$\begin{array}{l}\text { UKM communities' } \\
\text { practices on the use of } \\
\text { polystyrene }\end{array}$} & & & \\
\hline & & Correlation Coefficient & 0.045 & 1.000 \\
\hline & & Sig. (2-tailed) & 0.378 & 0.000 \\
\hline & & $\mathrm{N}$ & 381 & 381 \\
\hline
\end{tabular}

small (0.3). The null hypothesis is rejected. Knowledge and UKM policy in environmental programs especially in the context of polystyrene use has encourage greater involvement of UKM community in the environmental activities. Table 13 shows Spearman's correlation test findings.

\section{Discussion}

This study examines three important constructs that are knowledge of UKM communities on the advantages and disadvantages of polystyrene products, the practice of UKM communities on the use of polystyrene and the involvement of UKM communities in environmental activities organized by the university. These three constructs were measured to examine the awareness of UKM community towards the environment in the context of polystyrene use. The findings show that the knowledge level of UKM communities about the advantages and disadvantages of polystyrene products is at a good level with an average mean of 4.00. The practice of UKM communities on the use of polystyrene is moderately low at the average mean of 2.99 while the involvement of UKM communities in environmental activities organized by the university is at a moderate level with the average mean of 3.29 .

Ahmad et al. (2011) stated that the level of knowledge about the environment is at an unsatisfying level and stated that respondents need more exposure or explanation in enhancing their knowledge as well as improving their attitudes and practices towards the environment while Saidi and Er (2016) states that the knowledge of UKM students on the advantages and disadvantages of polystyrene use is at a moderate level. However, the findings from this study found that the knowledge of UKM residents on environmental issues in the context of polystyrene is at a good level. The implication of this study proves that today's society is already concerned about the importance of environmental knowledge. Various sources of environment related knowledge especially about materials such as plastic, polystyrene and bottles are available easily. Great discussions on environmental issues around the world specifically in Malaysia are sources of reference that leads to a sustainable knowledge in the community about the importance of environmental care.

The practice of UKM community on the use of polystyrene is at a moderate 
Table 13. Spearman's correlation findings for knowledge and involvement.

\begin{tabular}{|c|c|c|c|c|}
\hline & & & $\begin{array}{c}\text { Knowledge of } \\
\text { polystyrene products }\end{array}$ & $\begin{array}{c}\text { Involvement of UKM community } \\
\text { in the environmental activities } \\
\text { organized by UKM }\end{array}$ \\
\hline \multirow{6}{*}{ Spearman's rho } & \multirow{3}{*}{ Knowledge of polystyrene products } & Correlation Coefficient & 1.000 & $0.299^{* *}$ \\
\hline & & Sig. (2-tailed) & 0.000 & 0.000 \\
\hline & & $\mathrm{N}$ & 381 & 381 \\
\hline & \multirow{3}{*}{$\begin{array}{c}\text { Involvement of UKM community in } \\
\text { the environmental activities } \\
\text { organized by UKM }\end{array}$} & Correlation Coefficient & $0.299^{* *}$ & 1.000 \\
\hline & & Sig. (2-tailed) & 0.000 & $\cdot$ \\
\hline & & $\mathrm{N}$ & 381 & 381 \\
\hline
\end{tabular}

level based on the findings of the study. This suggests that although UKM communities have good knowledge of polystyrene, the practice of polystyrene use is still happening. The findings of this study are consistent with the findings of the previous study (Hadi, Yunos, \& Esa, 2003; Tan \& Azman, 2011), which found that the practice of environment of The National University of Malaysia communities are still not sufficient even if they have high knowledge on environmental care. This is because UKM communities think that polystyrene is more readily available and cheaper than eco-friendly packaging materials. Based on experience, the use of polystyrene still cannot be stopped because it has become a habit when buying packed food.

The involvement of UKM communities in environmental activities organized by the university is at a moderate level. The implication of this finding is that their involvement in environmental activities within the campus is on the instruction of the university. Most respondents only participate in environmental activities within the university at the demand of the administration and not voluntary. However, the findings of this study are contrary to the findings of Zain et al. (2015) which states that the level of students' volunteerism of the Faculty of Engineering and Architecture (UKM) are at high levels. The implication of this study is that not all faculties at UKM emphasize and require the involvement of their communities in environmental activities such as Faculty of Engineering and Architecture (UKM). This has led to the involvement of UKM communities in environmental activities not comprehensive and less effective.

In general, high knowledge in an individual will lead to a good practice (Bokhari, Hassan, \& Saadan, 2012). However, this study found that UKM communities' knowledge about the advantages and disadvantages of polystyrene use does not lead to good environmental friendly practices. The practice of an individual could not be measured from their knowledge. Based on the experience and the environment of the student, the sense of ego and self-indulgence of the individual itself has formed a bad practice towards others and the environment. UKM communities are knowledgeable thus they should practice the knowledge they have for their well-being, society and nature. Shaykh Abdurrahman bin Qasim An-Najdirahimahullah said, "Practice is the fruit of knowledge".

The results of the open question in the survey questionnaire found that most of the respondents felt that changing their habits from using polystyrene pack- 
aging materials to using environmentally friendly packaging materials was difficult because of several factors. The first factor is that eco-friendly packaging is charged compared to using polystyrene pack. The benefits of eco-friendly packaging materials lead to expensive charge rates for the consumer. This causes UKM communities to choose to use polystyrene because of zero charges. The use of polystyrene is still on-going as most university communities do not just buy food inside the campus. The respondents stated that they only practiced the use of polystyrene in the university campus as all the shops or cafes in the campus provided eco-friendly packaging materials. Food vendors outside UKM still use polystyrene as the main packaging material in their stores. Therefore, UKM communities who purchase packed food from outside indirectly use polystyrene as their food packaging material.

In general, UKM's efforts in injecting environmental knowledge through informal learning such as the prohibition of polystyrene use in cafes and food premises in the campus have altered the practice of university communities in the use of polystyrene. External factors such as polystyrene packaging materials from outside vendor and extra payment of eco-friendly packaging materials are the main source of polystyrene use among UKM communities at moderately low level despite having high knowledge about polystyrene.

\section{Conclusion}

The knowledge of National University of Malaysia communities on polystyrene is high but, the practice of using polystyrene and the rate of involvement of UKM communities in polystyrene-related environmental activities need to be improved. The implication of this study is that UKM needs to expand the restriction enforcement of polystyrene use within the campus to ensure that the campus area is free of polystyrene as a whole. UKM's efforts in improving environmental quality with various environmental activities such as prohibition of polystyrene use are a lifelong learning process that needs to be continued and emulated by many people. The findings of this study can contribute to the enhancement of knowledge on the implications of polystyrene use, the importance of environmental care and can be used as a reference for future research. This study presents a very universal theme that is environmental-themed but the scope of the study is only about the use of polystyrene. The suggestion for further study based on the findings of this study is to broaden the scope of the study on more environmental issues and to use the mixed method in the study so that the outcome of the study will be more meaningful and accurate.

\section{Acknowledgements}

This research was partially supported by Faculty of Education, Universiti Kebangsaan Malaysia Fund under the Dana FPEND 1 (Reference Number: 24530974).

\section{Conflicts of Interest}

The authors declare no conflicts of interest regarding the publication of this paper. 


\section{References}

Ahmad, J. H., Mustafa, H., Hamid, H. A., \& Wahab, J. A. (2011). Knowledge, Attitude and Practices of Malaysian Society Regarding Environmental Issues. Akademika, 81, 103-115.

Baba, A. (1992). Statistical Research in Education and Social Science. Bangi: Penerbit Universiti Kebangsaan Malaysia.

Bokhari, M., Hassan, S. N. S., \& Saadan, R. (2012). The Relationship between Understanding, Awareness, and Ethics of Confidentiality Practice among Malaysian Counsellors. Journal of Human Capital Development, 5, 63-73.

Callicott, J. B. (2000). Harmony between Man and Land: Aldo Leopold and the Foundation of Ecosystem Management. Journal of Forestry, 98, 4-13.

Chua, Y. P. (2006). Research Methodology. Selangor: McGraw-Hill Education.

Cohen, L., Manion, L., \& Morrison, K. (2001). Research Methods in Education. British Journal of Educational Studies, 48, 446-446.

Dana Gopal, N. M., Phebe, P., Kumar, E. S., \& Vani, B. K. K. (2014). Impact of Plastic Leading Environmental Pollution. Journal of Chemical and Pharmaceutical Sciences, Special Issue 3, 96-99.

Davis, G., O’Callaghan, F., \& Knox, K. (2009). Sustainable Attitudes and Behaviours amongst a Sample of Non-Academic Staff: A Case Study from an Information Services Department, Griffith University, Brisbane. International Journal of Sustainability in Higher Education, 10, 136-151. https://doi.org/10.1108/14676370910945945

Derahim, N., Ali, N., \& Saadiah, H. (2011). Menjejak Kelestarian Pelajar ke Arah Kampus Lestari: Kajian Kes Universiti Kebangsaan Malaysia. Jurnal Personalia Pelajar, 4, 1-10.

Hadi, M. Y. A., Yunos, J. M., \& Esa, A. (2003). Enhancing Knowledge, Practice and Attitudes towards Natural Education among Students. In Prosiding Seminar Kebangsaan Pengurusan Persekitaran (pp. 187-194). Bangi: Universiti Kebangsaan Malaysia.

Kamaruddin, S. B. (2015). Polystyrene Packaging Banned from UKM Campus. http://www.ukm.my/news/Latest_News/polystyrene-packaging-banned-from-ukm-ca mpus

Kollmuss, A., \& Agymen, J. (2002). Mind the Gap: Why Do People Act Environmentally and Hat Are the Barriers to Pro-Environmental Behavoiur? Environmental Education Research, 8, 239-260. https://doi.org/10.1080/13504620220145401

Konting, M. M. (2000). Educational Research Methodology (5th ed.). (Educational Research Methodology). Kuala Lumpur: Dewan Bahasa dan Pustaka.

Saidi, Z. A., \& Er, A. C. (2016). The Use of Environmentally Friendly Food Packaging in Malaysia: A Preliminary Study on Knowledge and Willingness of Students of National University of Malaysia. Malaysian Journal of Society and Space, 12, 113-126.

Tan, P. S., \& Azman, N. (2011). The Relationship between Commitment towards Environment and Pro-Environment Behaviour among University Students. Jurnal Personalia Pelajar, 14, 11-22.

Veratharaju, K., \& Idros, S. N. S. (2008). Pengukuhan Pengetahuan dan Kesedaran Alam Sekitar Melalui Permainan Simulasi Eksperiential. Malaysian Education Deans' Council Journal, 2, 1-11.

Zain, S. M., Junaidi, M. I. M., \& Basri, N. E. A. (2015). Environmental Volunteers: Students Acceptance and Understanding. Jurnal Personalia Pelajar, 18, 53-59. 